EPRA International Journal of Economic and Business Review-Peer Reviewed Journal Volume - 9, Issue -1, January 2021 | e-ISSN: 2347 - 9671| p- ISSN: 2349 - 0187

\title{
THE RELATIONSHIP BETWEEN REWARDS AND EMPLOYEE PERFORMANCE AMONG TELECOMMUNICATION EMPLOYEES IN YEMEN
}

\begin{tabular}{|c|c|}
\hline${ }^{1}$ Maged Mustafa Al-Dubai & ${ }^{1}$ Universiti Sultan Zainal Abidin, Malaysia \\
\hline${ }^{2}$ Mohd Sadad Mahmud & ${ }^{2}$ Universiti Sultan Zainal Abidin, Malaysia \\
\hline${ }^{3}$ Afrah Mohammed Hamood & ${ }^{3}$ Al-Madinah International University, \\
\hline
\end{tabular}

\section{ABSTRACT}

Article DOI URL: $\underline{\text { https://doi.org/10.36713/epra6038 }}$

The purpose of this study was to define the connection between rewards and employee performance. The study population included Public Telecommunication Corporation (PTC) employees who are based in Yemen. The researcher utilized Raosoft to determine the sample needed. The questionnaire was circulated to 365 workers, 262 of whom were selected from. The Social Sciences version 20 tool Statistical tool and many statistical approaches were used in the data and statistical analysis, including the maximum probability calculation. To consider the dimensionality of the variables, regression techniques were used. The study found that rewards and employee performance are strongly linked. Some theoretical and practical consequences have been explored, based on the research results.

KEYWORDS: Rewards, Employee Performance, Yemen

\section{INTRODUCTION}

The present era is witnessing a fierce competition waged between institutions. This has made them exert their best efforts to overcome the difficulties and problems to reach their primary objectives for survival, leadership, and continuity (Awarib, 2016).
In institutions, the human element is essential for its significant and influential role in the institutions' Performance, prosperity, and progress. Thus, the different departments of the institutions pay considerable attention to the human element (Workforce) therein by conducting research studying the factors that affect workers' productivity and 
efficiency to achieve the highest level of efficiency possible. In pursuit of this objective, institutions recruit a qualified workforce, conduct training courses and provide workers with new and essential skills to perform their tasks (Al-Dubai ,2019; Sani and Worlu, 2018).

Therefore, the rewards are among the means that contribute to supporting individuals at work to achieve the work objectives, represented in increasing productivity. Moreover, Rewards play an essential role in promoting the institution's job success for the staff. Administrative agencies benefit immensely from implementing incentives in various forms expressed in job results, such as concentrating efforts and assessing their efficacy and measuring employees' accomplishments and skills. Rewards are among the most critical factors that evaluate the workers' efficiency in the entity or institution (Ahmad et al, 2017; Al-Dubai\& Gopalan, 2019).

\section{RESEARCH QUESTION}

RQ1: Is there a relationship between rewards and employee performance?

\section{RESEARCH OBJECTIVE}

RO1: To examine the relationship between rewards and employee performance.

\section{HYPOTHESIS}

H1: There is a significant relationship between rewards and employee performance.

\section{LITERATURE REVIEW Rewards}

Since the attention was shifted to looking for individuals who can work efficiently to ensure adequate progress toward the organization's objectives, rewards occupied an important role. Rewards play a significant and essential part in employee productivity. The value of the incentives stems from the need for the individual to realize the significance of their actions and achievement. The appreciation of others' work through rewards is an essential matter that contributes to the satisfaction of the fundamental needs of interaction within the person (Ismajli, Zekiri, Qosja \&Krasniqi, 2016).

The material rewards are called direct compensation systems, which include salaries, wages, bonuses, etc. The moral rewards or the indirect compensation systems are related to job satisfaction and security, such as work stability, engagement in the decision making, commitment, feeling of belonging, promotions, and showing appreciation and gratitude to the workers' efforts. Thus, it is clear that the rewards are considered a result of excellent PerformancePerformance, whether in terms of quantity or quality, or in saving work time and costs (Rai, Ghosh, Chauhan, \& Singh, 2018).

\section{Performance}

The performance concept relates to the behaviour of the individual and the organization as well. It undertakes a significant role within the institution, for it is considered the outcome of activities therein. In other words, PerformancePerformance is carrying out the job duties, such as responsibilities and assignments, following the rate supposed to be performed by the competent and trained worker (Cairo,\& Cajner, 2018).

\section{METHODOLOGY}

The methodology is based on the study of the situation or phenomenon to provide a precise description. In this study, surveys approach a quantitative data collection method and have been utilized to collect employee rewards and employee performance by employees in the Yemeni telecommunications industry.

\section{Study Population}

The targeted study population consists of 800 employees of the Public Telecommunications Corporation (PTC) only takes branches in the Republic of Yemen and Sana'a and has 800 employees. Therefore, the sample size was (260) based on the (Raosoft) website.

\section{Sample Size}

The sample size refers to the total number of employees in the PTC, only taken from the Sanaa division, its population is 800 , and the sample size is 260. According to Sekaran Table and (Raosoft) website, the sample size used in this study was 260, as only the branch of Sana'a was taken, and 365 questionnaires were distributed to the employees. However, all that has been recovered is 262 questionnaires from which data and information for this analysis are gathered.

\section{Framework}

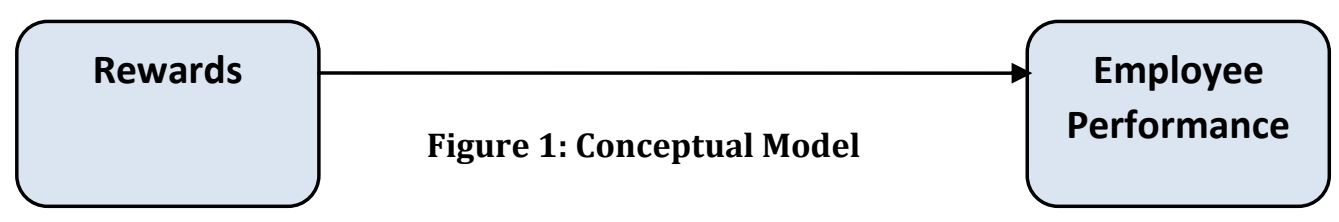




\section{RESULTS AND DISCUSSIONS}

The result indicated in table 1 discloses that reward and employee performance significant relationship with $(\mathrm{R}=0.815)$.

Table 1: Correlation Analysis

\begin{tabular}{c|c|c|c}
\hline \multicolumn{2}{c|}{} & Reward & Performance \\
\hline \multirow{3}{*}{ Reward } & Pearson Correlation & 1 & $.815^{* *}$ \\
\cline { 2 - 4 } & Sig. (2-tailed) & & .000 \\
\cline { 2 - 4 } & $\mathrm{N}$ & 262 & 262 \\
\hline
\end{tabular}

\section{Is there a relationship between reward and employee Performance?}

The $\mathrm{s}$ question was designed to discover if there is a positive relationship between reward and employee performance in a public organization in Yemen. Results analysis via regression analysis revealed that the reward revealed a significant positive relationship with employee performance in a public organization in Yemen.

H1: There is a significant relationship between rewards and employee performance.

Hochberg (1988) reported that the relationship of appositive significance between two variables is less than $0.01,0.05$ and 0.10 as they obtain P-value. Furthermore, Westfall (1993) said that the Sig value, which is less than 0.05 in the regression analysis test, means the two variables have a positive relation. Consequently, this paper's findings show a positive relationship between compensation and success of employees in Yemen's public organization, as Sig received. Value of $(\mathrm{P}=0.030)$, less than 0.05 . Thus, the researcher believes there is an essential connection between compensation and the success of the employees.

\section{CONCLUSION}

The researcher examined the findings in this paper based on the research questions; this study provides evidence that the incentives may play an essential role in improving employee performance and found that there are many forms of incentives that may be used in various ways that will ultimately enable the employee to work hard and perform well.

\section{Practical Implications}

The research could help national policymakers and even businesses. On the one hand, it supports the country in preparing the strategy and developing policies across the country to enhance employee performance at the national level and increase employee performance in Yemen's public organizations.

\section{Recommendations for further research}

Future researchers will improve current research regarding the sample size distribution's steadiness and regularity. In reality, this can be accomplished by making the questionnaires distributed or crafted similarly to a large number of participants. It is also proposed that potential researchers include more new variables that can affect the output of Yemen's employees, such as work protection and 4.0 technologies.

\section{Acknowledgement}

This work was supported by Universiti Sultan Zainal Abidin, Malaysia, and Al-Madinah International University.

\section{REFERENCES}

1. Ahmad, Ali, Nisar \& Ahmed(2017). Impact of Rewards, Recognition \& Job Stress on Job Performance and Job Satisfaction. International Journal For Research In Business, Management And Accounting (ISSN: 2455-6114), 3(4), 01-17.

2. Al-Dubai, M. M., Gopalan, V., Alaghbari, M. A., \& Hamood, A. M. (2019). THE MODERATING ROLE OF JOB SATISFACTION ON THE RELATIONSHIP BETWEEN HUMAN RESOURCE MANAGEMENT PRACTICES AND EMPLOYEE PERFORMANCE AMONG TELECOMMUNICATION

EMPLOYEES. Journal of Internet Banking and Commerce, 24(3), 1-22.

3. Al-Dubai, M. M., \& Gopalan, V. (2019). MEDIATING ROLE OF LEADERSHIP STYLES ON THE RELATIONSHIP BETWEEN RECRUITMENT AND SELECTION AND EMPLOYEE SATISFACTION AMONG TELECOMMUNICATION

EMPLOYEES. Journal of Internet Banking and Commerce, 24(2), 1-11.

4. Awarib and Alzahra. (2016). the role of rewards in improving the performance of employees. Doctoral dissertation.

5. Ismajli, N., Zekiri, J., Qosja, E., \& Krasniqi, I. (2015). The Importance of Motivation Factors on Employee Performance in Kosovo Municipalities. Journal of Public Administration and Governance, 5(1), 23-39.

6. Cairo, I., \& Cajner, T. (2018). Human capital and unemployment dynamics: Why more 
educated workers enjoy greater employment stability. The Economic Journal, 128(609), 652682.

7. Hochberg, Y. (1988). A sharper Bonferroni procedure for multiple tests of significance. Biometrika, 75(4), 800-802.

8. Rai, A., Ghosh, P., Chauhan, R., \& Singh, R. (2018). Improving in-role and extra-role performances with rewards and recognition: Does engagement mediate the process?. Management Research Review.

9. SANI, S. A., \& WORLU, G. O. (2018). HUMAN RESOURCE MANAGEMENT PRACTICES AND MANAGERIAL PERFORMANCE OF MANUFACTURING FIRMS IN NIGERIA. HUMAN

RESOURCE MANAGEMENT, 4(4).

10. Westfall, P. H., \& Young, S. S. (1993). Resampling-based multiple testing: Examples and methods for p-value adjustment (Vol. 279). John Wiley \& Sons 